International Journal of Management Science and

Business Administration

Volume 2, Issue 7, June 2016, Pages 16-24

URL: dx.doi.org/10.18775/ijmsba.1849-5664-5419.2014.27.1002

DOI: 10.18775/ijmsba.1849-5664-5419.2014.27.1002

\title{
Determinants of Preventing Cyber Crime: a Survey Research
}

\author{
Maziah Mohd Ali \\ Malaysian Institute of Marine Engineering Technology, Kuala Lumpur, Malaysia
}

\begin{abstract}
This paper presents the results of research on the determinants of preventing cyber crime among Bumiputera entrepreneurs involved in the online business. With regards to the cyber crime issues that has been tremendously become a national issue, thus, this research is carried out with the aim of identifying what are the determinants factor for preventing cyber crime to the online business entrepreneur in Malaysia and Perak specifically. The research looks upon the factors such as law enforcement, awareness program, and prevention process in combating cybercrime issue. A survey was conducted and the questionnaires were distributed to the respondents who were mainly online entrepreneurs. The data was gathered from three groups of online entrepreneurs; in the district of Kinta, Manjung and Larut, Matang \& Selama, Perak. The data was analyzed using Statistical Package for the Social Sciences (SPSS). Based on the result of this research, we found a positive relationship between preventing cyber crime against law enforcement, attitude awareness, ethics, and IT Technology. The research objective questions have also been met by the results of the analysis made on the sample of entrepreneurs. At the end of the chapter, there are some recommendations highlighted as a scheme to combat cyber crime issues and future research study for expansion and accuracy of the analysis.
\end{abstract}

Keywords: Cyber Crime, Law Enforcement, Attitude Awareness

\section{Introduction}

This study will focus on the determinants factor of preventing cybercrimes that are getting more prevalent in cyberspace against the backdrop of the Malaysian legal landscape. This cyber crime issue not also has become a viral in information system environment but knocks out as a general issue that could be harm national constitution. As national institution like Cyber Security Malaysia use to help to face the challenges, but there is no agreed indicator to measures the success. According to Cyber Security Malaysia, a very challenging part in cyber crime investigation is the gathering of evidence and most of the cyber crimes issues are financially motivated. The impact of the economic downturn and financial crisis could potentially lead to the increase in cyber crime cases globally. With regards to this challenge, this research to be done to find a solution and model of prevention, if any, with some sort of recommendation to overcome such challenge.

Cyber Crime which is also known as 'Internet crimes' or 'Computer crimes' is any criminal activity that uses a computer either as an instrument, target or a means for perpetuating further crimes or offenses or contraventions under any law (Binitha et. al., 2007). Cybercrime is generally regarded as any illegal activity conducted through a computer (Obuh \& Babatope, 2011). Mohamed (2003) emphasize cybercrime as a major concern to the global community. Creating awareness (Muniandy \&Muniandy , 2012) on cyber security issues is very important for Malaysians as Malaysia is seen as a progressing nation in the field of technology. The introduction, growth, and utilization of information and communication technologies (ICTs) have been accompanied by an increase in criminal activities (Obuh \& Babatope, 2011). There are four major categories of cyber crimes such a cyber crime against individuals, cyber crime against property, cyber crime against organization and cyber crime against society. (Brenner \& Goodman, 2002). Cyber crimes against individuals are hacking, email spoofing, spamming, cyber defamation and harassment, cyber stalking and cyber bullying. "Hacking in layman terms means an illegal intrusion into a computer system" (Supriya, 2012). Spoofed email is one which email header is forged so that mail appears to originate from one source but actually has been sent from another source. Spamming means sending multiple copies of unsolicited mails or mass 
e-mails such as chain letters. Cyber defamation takes place with the help of computers or the internet while cyberbullying is growing problem especially among teenagers (Parthasarathi, 2003). The second category of cyber crimes is that cyber crime against property such credit card fraud, intellectual property crimes includes software piracy, illegal copying of programs, distribution of copies of software, copyright infringement, trademarks violations and theft of computer source code (Supriya, 2012)."It is believed that credit card fraud was first reported in Malaysia in 1998" (Paynter \& Lim, 2011).Parthasarathi (2003) clearly stated that cybercrime against the organizationis such unauthorized accessing of computer, denial of service, virus attack, email bombing, salami attack, logic bomb, Trojan horse and data diddling. Malaysian Cyber Security also acknowledges that cyber crime against society such forgery in currency notes, revenue stamps, mark sheets also can be forged using computers and high-quality scanners and printers. "Cyber terrorism is the use of computer resources to intimidate or coerce others "(Sproles \& Byars, 1998) and web jacking is "hackers' gain access and control over the website of another, even they change the content of the website for fulfilling political objective or for money" (Supriya, 2012).

One major apprehension in Malaysian cyberspace environment is the incremental of cyber crime issue and the effect to online business entrepreneur.Another major challenge is how the existing legal law will prosecute cybercriminals and the difficulty in collecting evidential proof of computer crimes. "Globally, the law faces huge challenges in regulating the Internet" (Jiow, 2013) On such a basis, cybercrimes present new challenges to lawmakers, law enforcement agencies, and international institutions (Obuh \& Babatope, 2011). According to Lee (2005), Malaysia currently, does not have a data protection regime to protect the online user's personal information. Is there any framework or model done to protect online business entrepreneur in Malaysia? What are the contingency plan or mechanism to give awareness to anonline business entrepreneur about the dangers of cybercrime?

Based on the above discussion, the study aims to explain the cyber crime concept, generally in Malaysia and Perak specifically, issues related to cyber crime that may harm online business process, determinants factor of cyber crime prevention and suggest a way of combating this issue in present days of internet usage and applications

The following are the objectives:

- To determine awareness program in preventing cyber crime

- To identify what are the determinants factor for preventing cyber crime to the businesses in Malaysia.

- To propose cyber-crime prevention framework.

\section{Literature Review}

According to the PricewaterhouseCoopers (PWC), Global Economic Crime Survey November 2011, cyber-crime now ranks as one of the top four economic crimes globally with $23 \%$ of respondents reporting that they were victims of cyber crime.Previous research done by (Saini et. al, 2012) indicated that as many as $80 \%$ of the companies'surveyed acknowledged financial losses due to computer breaches and Saini (2012) also added "as the economy increases its reliance on the Internet, it is exposed to all the threats posed by cyber-criminals".

Cyber crime affect both small and medium enterprise (SMEs) in Malaysia and regardless no industry or any company in this world immune from this crime. According to (Sadique et. al., 2010), the number of reported cases of economic cybercrime committed by company employees in Malaysia is higher than that reported for the Asia-Pacific region and for other countries around the world.

\subsection{Lack of Law Enforcement}

Many developing countries lack appropriate law to tackle the cybercrime attackers (McConnell, 2000). Genuinely investment in law enforcement for cyber crime is too low, as compared with the investment in law enforcement for regular crime (Michael et. al, 2011). On such a basis, the new forms of cyber crime present new challenges to lawmakers, law enforcement agencies, and international institutions (Mohamed, 2003). Prior research done by (Lee, 2005) stated that Malaysia cyber law still fail to meet a certain standard, and the current laws and codes in Malaysia are to be amended.Attitude Awareness. According to (Muniandy \&Muniandy , 2012) creating attitude awareness on cybercrime issues is very important for Malaysians as Malaysia is seen as a progressing nation in the field of technology. Based on the previous study found that the importance of awareness as a tool to decrease or prevent cyber crime and they conclude that there is no association between the respondents occupation and level of awareness 
(Chauhan \& Arpana, 2012).Ethics. Mohit (2012) stated that some previous research hasbeen discussed on the different ethics in cyber crime including business ethics, legal ethics, bioethics, medical ethics, engineering ethics, and computer ethics. IT Technology. Prior study done by Mohamed (2003), relate that IT Technology can prevent cyber crime as he stated "One of the best weapons against technology crimes is technology." The cyber security tools and activities include firewalls, content filters, intrusion detection and prevention systems, access control, strong user authentication, cryptography, hardening, auditing, end-user and administrator training and insurance (Gallaher et. al., 2008).

\subsection{Theoretical Framework}

Researchers have determined four independent variables namely law enforcement, attitudes awareness, ethics and IT Technology. The researchers want to study the variables that have significant positive relationship commitment. Figure-1 shows a theoretical framework on the relationship between the independent variables and their correlation with the dependent variable.

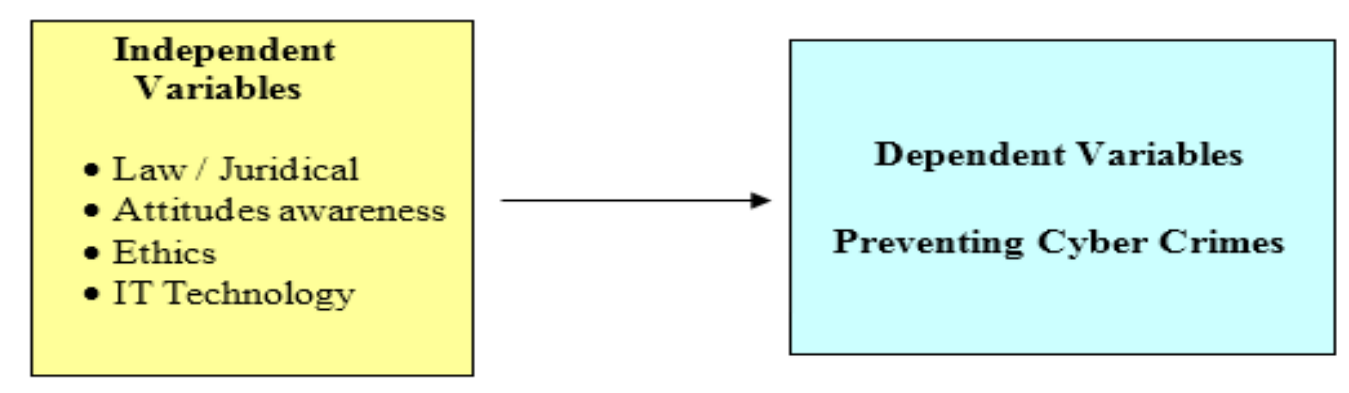

Figure 1: Schematic Diagram for the Theoretical Framework In The Determinants of Preventing Cyber Crime

\subsection{Hypothesis building}

Based on the independent and dependent variables shown above, the following hypotheses are proposed.

H1: $\quad$ There is a positive relationship between law enforcement and cyber crimes

H2: $\quad$ There is a positive relationship between attitudes and cyber crimes

H3: $\quad$ There is a positive relationship between ethics and cyber crimes

H4: $\quad$ There is a positive relationship between Technical and cyber crime

\subsection{Limitation of the study}

- Limitation on specific prima data from Perak Royal Malaysian Police, Commercial Crime Investigation Department.

- How laws are made. This area includes on how the governance legislative level can share to solve and prevent cyber crime.

- Insufficient data provided by my CERT

\section{Research Methodology}

\subsection{Data collection}

The research collects primary data by using quantitative methods. A questionnaire is a research instrument consisting of a series of questions and other prompts for the purpose of gathering information from respondents. The secondary data was collected from many sources, including literature, journals, and articles that related to the subject matter. In order to have smooth information, the research has formed a qualitative question to obtain comments and recommendations from respondents about awareness and current law protection of cyber crime in Malaysia.

\subsection{Target Population}

The target population in this research will comprise of all registered business online entrepreneurs in three districts in Perak, which is Kinta, Manjung and Larut, Matang \& Selama. 


\subsection{Sample Size}

Sample consisted of entrepreneurs involved in the online business in the district of Kinta, Manjung and Larut, Matang $\&$ Selama that have the characteristics of the population. Total online business entrepreneurs in the three districts are estimated at 522 persons regardless of sex, age, and type of business. The researcher used 150 respondents for the survey, and it was evenly distributed across the three districts with about 50 respondents in each district see Table-1.

Table 1: Summary of Online Entrepreneurs from the Year 2014-2015 for the District Of Kinta, Larut, Matang \& Selama and Manjung

\begin{tabular}{|c|c|c|c|c|c|c|}
\hline \multirow{2}{*}{ DISTRICT } & \multicolumn{2}{|c|}{ KINTA } & $\begin{array}{c}\text { LARUT, MATANG \& } \\
\text { SELAMA }\end{array}$ & \multicolumn{3}{c|}{ MANJUNG } \\
\hline YEAR SECTOR & 2014 & 2015 & 2014 & 2015 & 2014 & 2015 \\
\hline $\begin{array}{c}\text { TRADING } \\
\text {-No of entrepreneurs }\end{array}$ & 388 & 488 & 204 & 300 & 284 & 336 \\
-No of business online & 95 & 140 & 46 & 78 & 67 & 92 \\
\hline $\begin{array}{c}\text { SERVICE } \\
\text {-No of entrepreneurs }\end{array}$ & 97 & 122 & 51 & 75 & 71 & 84 \\
-No of business online & 2 & 0 & 0 & 0 & 0 & 2 \\
\hline $\begin{array}{c}\text { TOTAL } \\
\text {-No of entrepreneurs }\end{array}$ & 485 & 610 & 255 & 375 & 355 & 420 \\
-No of business online & 97 & 140 & 46 & 78 & 67 & 94 \\
\hline
\end{tabular}

\subsection{The Quantitative Method}

A five-point Likert-type scale was used throughout the survey, (for example, 1=Strongly Disagree, 2=Disagree, 3=Neither Agree, 4=Agree, 5=Strongly Agree) ,Likert-type scales use numbers to assess objects on certain attributes and assume equal increments of the attribute being measured. The structure of this questionnaire consists of seven sections (A) General information (B) Preventing cybercrime (C) Law enforcement (D) Awareness (E) Ethics (F) IT Technology (G) open-ended questions. Section A requires respondents to indicate only of six questions that gather demographic information presented in this section. Meanwhile, the question of Section B,C,D,E, and F was built by the researcher.

\section{Results and Discussion}

In this research, it can be concluded that average entrepreneur that involved in online business are thosein Table- 2 as follows:

Table 2: Conclusion of the respondents' demographic distribution

\begin{tabular}{|c|c|c|}
\hline ITEM & & Percent \\
\hline Gender & Female & $60.00 \%$ \\
\hline Age & 26 to 40 years & $40.00 \%$ \\
\hline Marital Status & Married & $68.70 \%$ \\
\hline Education & Secondary & $36.00 \%$ \\
\hline District & All districts & $33.30 \%$ \\
\hline Household Income & Below RM5,000 & $88.80 \%$ \\
\hline
\end{tabular}

\subsection{Descriptive Analysis}

In this study, Likert-type scale measure the options from 1 to 5 "(1) Strongly disagree” to "(5) Strongly agree” was used to allow the respondents to answer the question 
Table 3: Descriptive Analysis

\begin{tabular}{|c|c|c|}
\hline DEPENDENT VARIABLE & MEAN & STANDARD DEVIATION \\
\hline Preventing Cyber Crime & 19.06 & 5.011 \\
\hline INDEPENDANCE VARIABLE & MEAN & STANDARD DEVIATION \\
\hline Law Enforcement & 22.94 & 6.873 \\
Awareness & 16.11 & 9.409 \\
Ethics & 23.78 & 5.312 \\
\hline
\end{tabular}

The above table showed the mean and standard deviation of the four independent variable. The results have demonstrated ethics independent variable showed the highest mean value of the 23.78 and the mean of awareness independent variable is the lowest at 16.11 .

\subsection{Reliability Test}

Reliability analysis performed to evaluate the reliability of the data obtained throughquestionnaires distributed to respondents.

Table 4: The Reliability (Cronbach's Alpha)

\begin{tabular}{|c|c|c|c|}
\hline Dependent Varible & Number of item & Number of item deleted & Alpha Value \\
\hline Preventing Cyber Crime & 7 & 1 & 0.753 \\
\hline Independent Variable & Number of item & Number of item deleted & Alpha Value \\
\hline Law enforcement & 7 & 1 & 0.975 \\
Awarencess & 7 & 2 & 0.946 \\
Ethics & 7 & - & 0.944 \\
IT Technology & 7 & 2 & 0.966 \\
\hline
\end{tabular}

Table 4 showed that the reliability of dependent and independent variable $\alpha$ are above 0.70 and it sexplained that reliability value is consistent and stable. While, the independent variable. The highest independent variable Alpha Value is law enforcement $\alpha=0.975$ while the lowest is ethics with $\alpha=0.944$.

\subsection{Data Analysis Technique}

Two technique are usedto extract the result.

a) Correlation

b) Regression

\subsubsection{Correlation Test}

Pearson stated a correlation of 1 or -1 Means that the variables are perfectly correlated. As Shown in Table- 5 below, the entry in the matrix of correlation where the 'preventing cyber crime column and 'law enforcement' row meet is the number .966. This is Pearson correlation between preventing cyber Crime and law enforcement.

Table 5: Correlation Matrices Test Results

\begin{tabular}{|l|l|l|l|l|l|l|}
\hline & & $\begin{array}{l}\text { Preventing } \\
\text { Cyber Crime }\end{array}$ & $\begin{array}{l}\text { Law } \\
\text { Enforcement }\end{array}$ & Awareness & Ethics & $\begin{array}{l}\text { IT } \\
\text { Technology }\end{array}$ \\
\hline \multirow{5}{*}{$\begin{array}{l}\text { Pearson } \\
\text { Correlation } \\
\mathrm{P}<0.001 * *\end{array}$} & $\begin{array}{l}\text { Preventing } \\
\text { Cyber Crime }\end{array}$ & 1.000 & & & & \\
\cline { 2 - 8 } & Law enforcement & 0.966 & 1.000 & & & \\
\cline { 2 - 8 } & Awarencess & $0.953^{* *}$ & & 1.000 & & \\
\cline { 2 - 8 } & Ethics & $0.909^{* *}$ & & & 1.000 & \\
\hline
\end{tabular}




\subsubsection{Regression Analysis}

Table- 6 showed the highest standard coefficient is law enforcement variable with the value of 0.934 . Standard Coefficient (Beta) for law enforcement is $(\beta=0.966(p<0.01)$, has the greatest contribution of $96.6 \%$ to the variance in preventing cyber crime. Instead, the standard coefficient (Beta) for variable IT technology is only worth $(\beta=0.878$ $(\mathrm{p}<0.01)$, which has a relatively small contribution of only $8.8 \%$ of the variance commitment to preventing cyber crime. Durbin-Watson values are between 0.172 to 0.537 then have to prove that there is no autocorrelation as the value is in the range of 1.50 to 2.50 . During this test, $\left(\mathrm{R}^{2}=0.934\right)$ where the value of $\left(\mathrm{R}^{2}\right)$ closer to 1.0 means the percentage contributed by the researcher is more accurate.This means that there is a $93.4 \%$ variation $\left(\mathrm{R}^{2}\right)$ can be explained or be accounted by the variable of law enforcement. Accordingly, based on the significant value of $\mathrm{F}=$ $0.000 \mathrm{P}<0.01$ then the hypotheses $\mathrm{H}_{1}, \mathrm{H}_{2}, \mathrm{H}_{3}, \mathrm{H}_{4}$ are valid and acceptable.

Table 6: Coefficients Regression Analysis on Preventing Cyber Crime

\begin{tabular}{|c|c|c|c|c|c|c|}
\hline \multirow{2}{*}{$\begin{array}{c}\text { Independent } \\
\text { Variables }\end{array}$} & $\begin{array}{c}\text { Standart } \\
\text { Coefficients } \\
\text { Beta }\end{array}$ & $\mathbf{R}^{2}$ & Adjusted R & $\begin{array}{c}\text { Sig. F } \\
\text { Change }\end{array}$ & $\begin{array}{c}\text { F } \\
\text { Change }\end{array}$ & $\begin{array}{c}\text { Durbin- } \\
\text { Watson }\end{array}$ \\
\hline $\begin{array}{c}\text { Law } \\
\text { Enforcement }\end{array}$ & 0.966 & 0.934 & 0.933 & 0.000 & 2084.957 & 0.414 \\
\hline Awareness & 0.953 & 0.907 & 0.907 & 0.000 & 1449.293 & 0.537 \\
\hline Ethics & 0.909 & 0.827 & 0.826 & 0.000 & 708.231 & 0.172 \\
\hline $\begin{array}{c}\text { IT } \\
\text { Technology }\end{array}$ & 0.878 & 0.770 & 0.769 & 0.000 & 496.598 & 0.189 \\
\hline
\end{tabular}

\subsection{Hypothesis Test Result}

As a conclusion, to the entire hypothesis test conducted between independent variables and dependent variable can be derived into Figure-2 below.

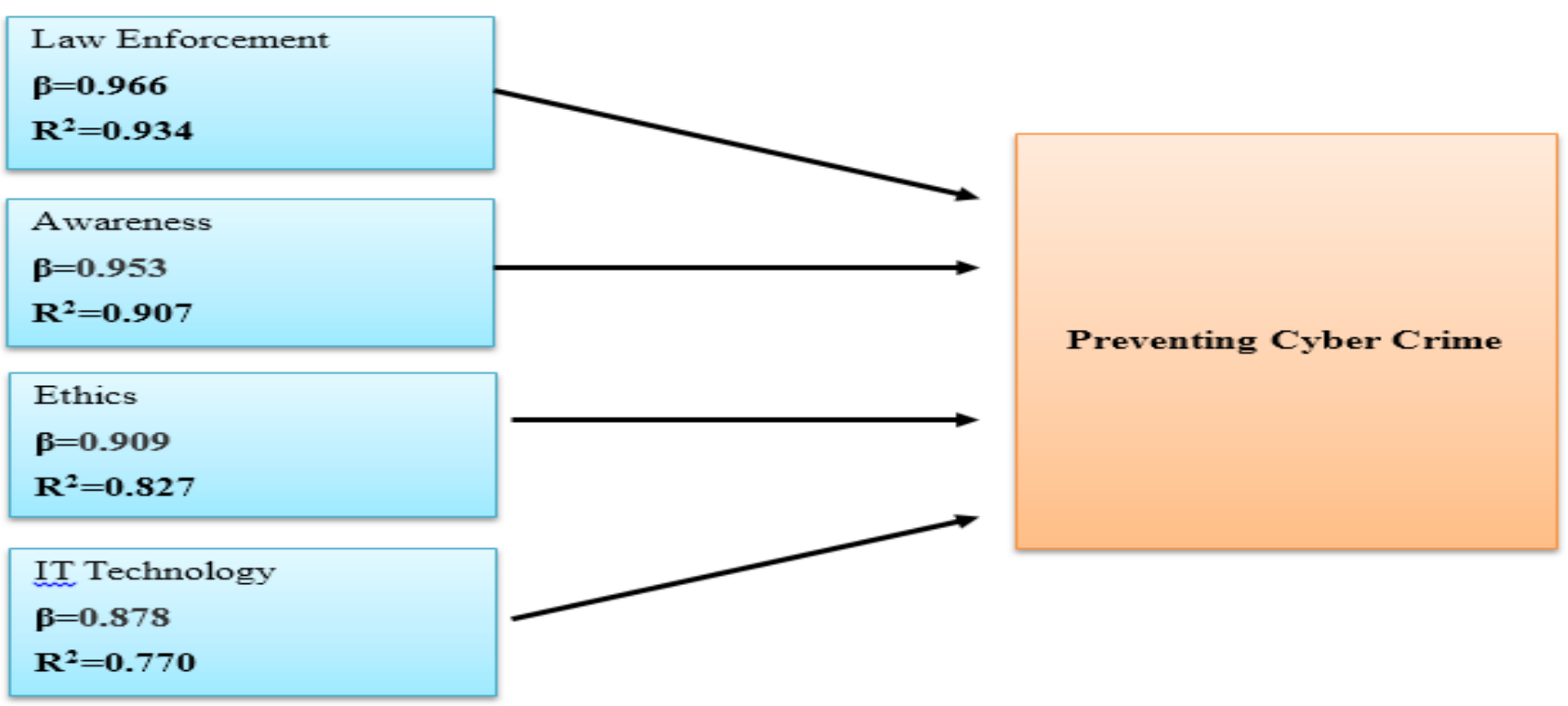

Figure 2: Positive Relationship between Independent and Dependent Variable

\section{Discussion of the results}

Positiveresultsinhypothesis1 thatthere is a positive relationship between preventing cyber crime against law enforcement $(\beta=0.966$ ( $p<0.01)$ where contributions shown by the independent variableis $94.60 \%$ of variance law 
enforcement among entrepreneurs. Positiveresultsinhypothesis2thatthere is a positive relationship between preventing cyber crime against awareness $(\beta=0.953(\mathrm{p}<0.01)$ where contributions shown by the independent variableis $95.30 \%$ of variance awareness among entrepreneurs. While Hypothesis 3 that there is a positive between preventing cyber crime against ethics $(\beta=0.909(p<0.01)$ where contributions shown by the independent variableis $90.9 \%$ of variance ethics among entrepreneurs. Positive results in hypothesis 4 that there is a positive relationship between preventing cyber crime against IT Technology $(\beta=0.878(\mathrm{p}<0.01)$ where contributions shown by the independent variableis $87.80 \%$ of variance IT Technology among entrepreneurs.

\subsection{Awareness Program in Preventing Cyber Crime}

From the survey done, $76.67 \%$ of the respondent stated that the awareness programme in preventing cyber crime has been carried out. As stated from the research the Malaysian government through Cyber Security Malaysia which reports to the Ministry of Science, Technology and Innovation (MOSTI) was the first agency establishes Cyber 999 Help Centre, which was set up in July 2009. The general public can report any types of cyber crimes through their website, www.cybersecurity.my. Cyber Security is responsible for designing awareness programs, various types of seminars, training and talk shows for everyone. The Royal Malaysian Police under the Commercial Crime Department has a responsibility to give an awareness program on cyber crime cases bygiving talks, seminars and distribute pamphlets to the people. The banking industry also creates awareness on cybercrime by sending alert notices to the customers through short messaging services (SMS), e-mail and place security notices at the Auto Teller Machine (ATM). The Malaysian Crime Prevention Foundation (MCPF) is Non-Government Organization responsible for creating cyber crime prevention awareness programs in school and universities in order to create more awareness.

\subsection{Determinants Factor for Preventing Cyber Crime}

\subsubsection{Law Enforcement}

From the survey done, $94 \%$ of the respondent stated the law enforcement is very weak. Therefore, in order to strength the law, the maximum fine should increase as well as imprisonment so that the guilty will be charged.

\subsubsection{Attitude awareness}

In order to prevent cyber crime, creating attitude awareness during online business is important. Business entrepreneurs from the survey are an aware cyber crime. Thus, awareness programme on preventing cyber crime should educate them in order to ensure entrepreneurs feel safe during online business transaction.

\subsubsection{Ethics}

From the survey done, $60.67 \%$ of the respondents stated that a good ethics while doing online business transaction should be addressed by entrepreneurs. They should respect potential buyers and seller by giving detail information and respect each other during online business.

\subsubsection{IT Technology}

From the survey done, $92 \%$ of the respondent stated that information technology infrastructure in Malaysia is comprehensive. Thus, cyber crime prevention strategies should remain a top concern as enterprise now must support more devices such tablets and smartphones. The enterprise should equip them with knowledge and update technology security devices so that can protect from cyber criminals.

\subsection{Cybercrime prevention framework}

This section answers the third research objective to propose cybercrime prevention framework.

Figure 3 shows example of cyber-crime prevention framework obtained from the survey done in order to look at cybercrime prevention from the perspective of government and non-government organizational (NGO). Prevention of cybercrime highlight that government leadership plays an important part in crime prevention, combined with cooperation and partnerships across ministries and between authorities, community organizations, non-governmental organizations, the business sector and private citizens. 


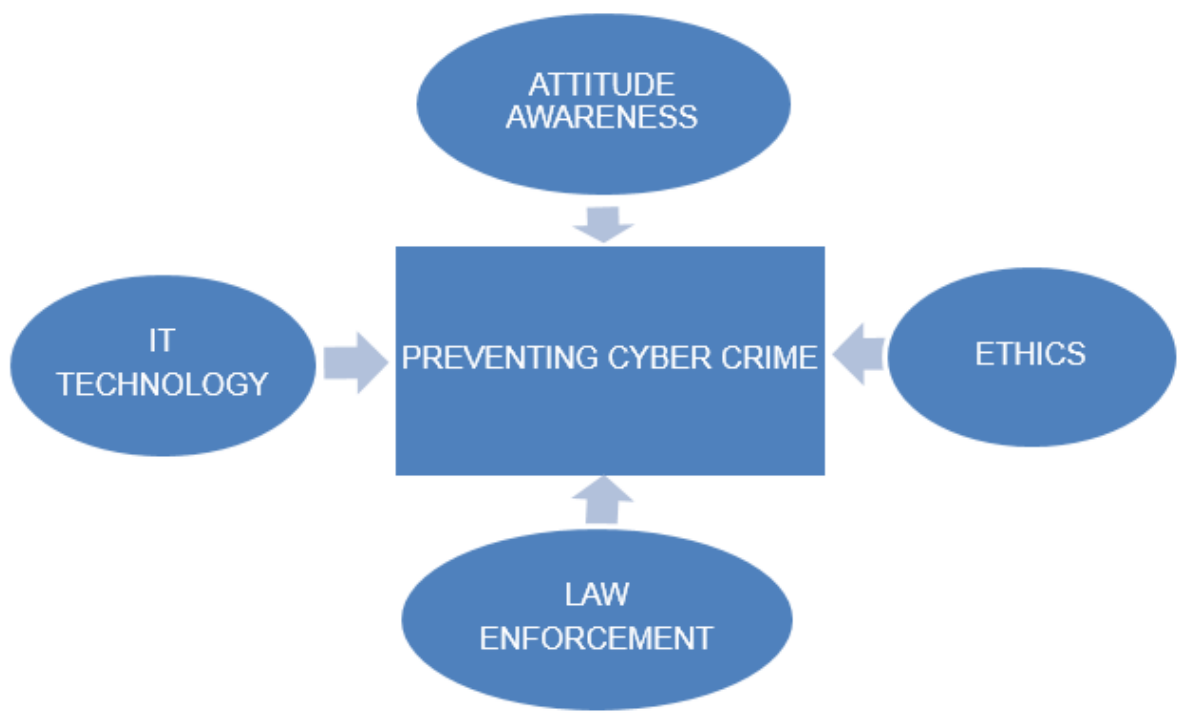

Figure 3: Cyber Crime Prevention Framework

\section{Recommendations and Conclusions}

This research identifies four factors such law enforcement, attitude awareness, ethics and IT technology have impact toward preventing cyber crime. At present law enforcement such Computer Act 1997, Copyrights Act, Communications, and Multimedia Act and Penal Code should be review by the government in parliament so that the new amendment will protect online business users. Creating attitude awareness during online business transaction is important to help both parties' seller and buyer. Apply good ethics will increase trust toward buyers while online business transaction. The business entrepreneur should equip with latest information technology, and updated security system will prevent being attack by a cyber-criminal.

In conclusion, Malaysia, in its bid to be technologically advanced has put into place its various national Information Communication and Technology (ICT) projects such as the Multimedia Super Corridor and the various technology parks to promote the use and development of ICT. Such promotion will result in a widespread use of the Internet and the Internet culture. It is submitted that Malaysia must have up-to-date lawsto deal effectively with the cybercrimes that come along with the Internet. To this end, Malaysia must constantly check and conduct measurements to determine the usage of its current laws to combat cybercrime. One cannot deny that the online environment cannot and will never be clear of cybercrimes due to the Internet's unique architecture.

\section{Acknowledgement}

I would like to express my deepest appreciation and heartful thanks to my supervisor, Dr. Puteri Nor Hashimah bt Megat Abdul Rahman, who always encouraged, guided and gave moral support from the initial stage until this research was completed. Special thanks to Commercial Crime Investigation Department (CCID) Royal Malaysian Police in Perak forthe unpublishedreport on Cyber Crime. Also, the most profound gratitude goes to my parents, family, colleagues, and friends for their unconditional love and steadfast support always. Thank you for the understanding.

\section{References}

- Binitha et. al. (2007). Cyber Crimes and Information Frauds. Recent Advances in Information Science \& Technology, Recent Advances in Information Science \& Technology Journal, pp 1-3.

- Brenner, S. W., \& Goodman, M. D. (2002). The Emerging Consensus on Criminal Conduct in Cyberspace. pp 2-3.

- Chauhan, M., \& Arpana. (2012). Preventing Cyber Crime: A Study Regarding Awareness Of Cyber Crime In Tricity. International Journal of Enterprise Computing and Business Systems,ISSN (Online): 2230-8849,Vol. 2 Issue 1 January 2012, pp 2-7.

- Cybersecurity level in Malaysia better than those in developed countries. (2009). Retrieved May 12, 2011, from

- Gallaher et. al. (2008). Cyber Security. United States: Cheltenham: Edward Elgar Publishing Limited. 
http://www.cybersecurity.my/en/knowledge bank/ ews/2009/main/detail/1725/index.html http://www.pwc.com/my/en/press/111130-global-economic-crime-survey.jhtml

- Jiow, H. J. (2013). Cyber Crime in Singapore: An Analysis of Regulation based on Lessig's four Modalities of Constraint. International Journal of Cyber Criminology, pp 20-21.

- Lee, S. Y. (2005). An Introduction To Cybercrimes: A Malaysian Perspective. An Introduction To Cybercrimes: A Malaysian Perspective, pp5

- Malaysian Computer Emergency Response Team (MyCERT).MyCERT IncidentStatistics (2011) February 6, 2013 from http://www.mycert.org.my/en/services/statistic/mycert/2011/main/detail/795/index.html

- McConnell. (2000). Cyber Crime and Punishment. McConnell International LLC.

- Michael et. al. (2011). COMBATING CYBERCRIME Principles, Policies and Program. Paypal.

- Mohamed, C. (2003). A critical look at a regulation of cyber crime, pp3-4.

- Mohit, G. (2012). ETHICS AND CYBER CRIME IN INDIA. International Journal of Engineering and Management Research, Vol. 2, Issue-1 pp 1-3

- Munir Abu Bakar;Mohd Yasin Siti Hajar. (2011). Information and Communication Technology Law. Petaling Jaya: Petaling Jaya Sweet \& Maxwell Asia

- Obuh, A. O., \& Babatope, I. S. (2011). Cybercrime Regulation:The Nigerian Situation. pp.7-8

- Paynter, J., \& Lim, J. (2011). Drivers and Impediments to E-commerce In Malaysia. Malaysian Jurnal of Library and Information Science, Vol 6,no2, pp1-19.

- Pricewaterhouse Coopers Global Economic Crime Survey November 2011, Retrieved Mar 7, 2013 from

- Sadique et. al. (2010). World Academy of Science, Engineering and Technology 42. Corporate Fraud: An Analysis of Malaysian Securities Commission Enforcement Releases, pp1-2

- Saini et. al. (2012). Cyber-Crimes and their Impacts: A Review. International Journal of Engineering Research, pp 202-209.

- Sproles, J., \& Byars, W. (1998). Cyber-terrorism.Computer Ethics at ETSU.

- Supriya, K. (2012). Cyber Crime. National University of Study and Research In Law, Ranchi University, pp7. 